\title{
Investigation of Relationship between Study Habits and Achievement Motivation of College Students
}

\author{
Dr. Indrajitsinh. D. Thakor ${ }^{1 *}$
}

\section{ABSTRACT}

Educational psychology is considered as an important branch of modern psychology. In it with study of behavior of a child to an old man is done scientifically in context of his learning environment. And the concept of motivation has taken many forms; It appears in our folklore, in our traditions and customs, in our great philosophical systems, and in our more recent science of behavior. The common and unifying element in these diverse conceptions is that motivation is an agency or factor or force that helps to explain behavior. The purpose of this study was to explore the relationship between Study Habits and Achievement motivation of college students of Halol city in Gujarat state. In this research paper Study Habits inventory and Achievement Motivation inventory was used. The random sample $(\mathrm{N}=111)$ was taken from college. The product-moment coefficient of correlation method and " $\mathrm{t}$ ” test was calculated to find out the result. Results showed positive relationship between Study Habits and Achievement motivation. It was also found that Study Habits and Achievement motivation are not gender sensitive. The high group of Study Habit students has achieved high results in Achievement then the low group of Study Habits students. The detail results are indicating in the paper.

Keywords: Relationship, Habits, Achievement, Motivation, College, Student

Learning is a highly complex problem in psychology. We know that different psychologists have tried to explain it in their own ways. Many factors greatly influence the process of learning aptitudes viz, heredity, effects of environment, his maturity, his interest in the subject and capacity of understand, member of his family, friends, qualities of teacher, methods of learning etc.

Mostly every student selects a particular method of study on the basis of his Study Habits and Attitudes. Study Habits undoubtedly make invaluable contribution to student's future academic achievements and professional successes. Hence, it is necessary to acquire the knowledge of Study Habits and Attitudes of students by scientific methods.

\footnotetext{
${ }^{1} \mathrm{M} \& \mathrm{~V}$ Arts and Commerce College, Halol

*Corresponding Author

(C) 2015 I I Thakor; licensee IJIP. This is an Open Access Research distributed under the terms of the Creative Commons Attribution License (http://creativecommons.org/licenses/by/2.0), which permits unrestricted use, distribution, and reproduction in any Medium, provided the original work is properly cited.
} 
Achievement Motivation is relatively a new concept in the global world of motivation. The basis of Achievement Motivation is achievement motive. Those who engage themselves in the task on account of an achievement motive are said to work under the spirit of achievement motivation. Therefore in order to understand the meaning of the term achievement motive it is essential to know in detail the nature and meaning of achievement motive. The motivation model of McClelland postulates that effect is conditioned to stimuli by mere association. The more frequently pleasure or un-pleasure is associated with neutral stimuli, the stronger will be the association formed and the more likely it is that this formerly neutral stimulus will evoke effect in the future.

McClelland's achievement is currently assessed through a written test given in one of several forms. Subjects are asked to write creative stories based on stimuli which are sufficiently ambiguous to allow many possible interpretations. After the stories are written, they are scored on the basis of the amount of "achievement imagery" in the stories. It is assumed that the stories reflect the motives of the writers. Projective technique is the generic term for tests which result in subjects revealing things of theoretical interest about themselves through stories created as a result of ambiguous or unstructured stimuli allowing various interpretations. The McClelland system for measuring motivation is objectified to allow a minimum of subjective evaluation. One of the techniques used by the McClelland group to measure motivation stems from the earlier work of Murry.

\section{OBJECTIVES}

1. To investigate the relationship between Study Habits and Achievement of college students.

2. To compare the Study Habits of male and female of college students.

3. To compare the Achievement Motivation of male and female of college students.

4. To compare the Achievement Motivation who have high and low Study Habits of college students.

\section{METHODOLOGY}

\section{Sample:}

The sample of the present study consists of 32 Male and 79 Female (Total sample: 111). They are randomly selected from college students.

\section{Tool:}

Study Habits and Attitudes Inventory, Constructed and Standardized by Dr. I. D. Thakor (2014) were used. This inventory consisted of 29 items which includes 16 positive and 13 negative statements.

Achievement Motivation, Constructed and Standardized by Dr. Ashwin Jansari (2006) to measure the Achievement Motivation of schools and colleges students. The split-half Reliability 
and Test Re-Test Reliability is shown 0.72 and 0.63 respectively. ( $\mathrm{N}=120)$. Validity of test with Thematic Apperception Test (TAT) is shown $0.54(\mathrm{~N}=50)$. The scale consists of 25 items.

\section{Hypotheses:}

HO:(I) There is no significant relationship between Study Habits and Achievement Motivation of college students.

HO:(II) There is no significant difference between Study Habits of male and female of college students.

HO:(III) There is no significant difference between Achievement Motivation of male and female of college students.

HO:(IV) There is no significant difference between Achievement Motivation of college students who have high and low Study Habits.

\section{Procedure:}

The data has been collected in small groups in the classroom situation. During the testing session respondents were instructed in brief about the purpose of investigation. They were instructed to read the items carefully and to put a tick mark before one of the items. According to their selected opinion and one by one calculation row scores of all forms and found out the productmoment coefficient of correlation " $r$ ” MEAN, SD and “ $t$ ” Value of respondents.

\section{RESULTS AND DISCUSSION}

The findings of the study on problem of relationship between Study Habits and Achievement Motivation of college students. The product-moment coefficient of correlation “ $\mathrm{r}$ " was calculated to find out the result. The results of data analysis are presented in the following tables. Table, I, Coefficient of Correlation “ $r$ ” Between Study Habits and Achievement Motivation of College Student.

\begin{tabular}{|l|l|l|l|l|l|}
\hline Sr. No & Groups & N & df & “r” & Sig. Level \\
\hline 01 & Study Habits Inventory & 111 & \multirow{2}{*}{109} & \multirow{2}{*}{0.25} & \multirow{2}{*}{0.01} \\
\hline 02 & Achievement Motivation & 111 & & & \\
\hline
\end{tabular}

$(\mathrm{N}=111)$

Table No: I Shows a correlation coefficient of $0.25 \mathrm{P}<0.01$. Hence, the null hypothesis stated. Above hypothesis is rejected in favor of the alternative hypothesis. This means that there is a positive relationship between Study Habits and Achievement Motivation of college student.

Table: II, MEAN, SD and " $t$ " Value of Gender difference of Study Habits and Attitudes Inventory of College Students.

\begin{tabular}{|l|l|l|l|l|l|l|l|}
\hline Sr. No & Gender & N & Mean & S.D. & df & “t” Value & Sig. Level. \\
\hline 01 & Male & 32 & 19.34 & 4.46 & \multirow{2}{*}{109} & \multirow{2}{*}{0.66} & \multirow{2}{*}{ NS* } \\
\hline 02 & Female & 79 & 19.67 & 3.99 & & & \\
\hline
\end{tabular}

$(\mathrm{N}=111)$

$*$ NS $=$ Not Significant. $\quad$ Table Value. $=1.98$

Level of Significant. $=0.05 \quad$ Calculated “ $t$ ” $=0.66$ 
Table No: II, Shows the mean scores of Study Habits and Attitudes Inventory between Male and Female of college students are 19.34 and 19.67 respectively. The " $\mathrm{t}$ " value difference between Male and Female of college students are 0.66, which is not significant at 0.05 level. The table value is 1.98 at $109 \mathrm{df}$. Therefore the null hypothesis is accepted. Therefore, it can be said that there is no significant difference between mean scores of Study Habits and Attitudes Inventory between Male and Female of college students. It is concluded that gender is not a factor for affecting Study Habits and Attitudes Inventory of college students. The main reason for almost equal Study Habits and Attitudes of Male and Female is because they are studying together with the same teaching and learning methods in the class rooms.

Table: III, MEAN, SD and " $t$ " Value of Gender difference of Achievement Motivation of College Students.

\begin{tabular}{|l|l|l|l|l|l|l|l|}
\hline Sr. No & Gender & N & Mean & S.D. & df & “t” Value & Sig. Level. \\
\hline 01 & Male & 32 & 16.94 & 10.50 & \multirow{2}{*}{109} & \multirow{2}{*}{0.41} & \multirow{2}{*}{ NS* } \\
\cline { 1 - 4 } 0 & Female & 79 & 18.04 & 9.79 & & & \\
\hline
\end{tabular}

$(\mathrm{N}=111)$

$* \mathrm{NS}=$ Not Significant.

Table Value. $=1.98$

Level of Significant. $=0.05$

Calculated " $\mathrm{t}$ ” $=0.41$

Table No: III, Shows the mean scores of Achievement Motivation between Male and Female of college students are 16.94 and 18.04 respectively. The " $t$ " value difference between Male and Female of college students are 0.41 , which is not significant at 0.05 level. The table value is 1.98 at $109 \mathrm{df}$. Therefore, the null hypothesis is accepted. Therefore, it can be said that there is no significant difference between mean scores of Achievement Motivation between Male and Female of college students. It is concluded that gender is not a factor for affecting of Achievement Motivation of college students. The main reason for almost equal Achievement Motivation of Male and Female is because they are studying together with the same teaching and learning methods in the class rooms.

Table: IV, MEAN, SD and “ $t$ " Value of Study Habits and Attitudes difference in participant's Achievement Motivation.

\begin{tabular}{|l|l|l|l|l|l|l|l|}
\hline Sr. No & Gender & N & Mean & S.D. & df & “t” Value & Sig. Level. \\
\hline 01 & High & 50 & 18.62 & 8.92 & \multirow{2}{*}{109} & \multirow{2}{*}{2.13} & \multirow{2}{*}{0.05} \\
\cline { 1 - 4 } 02 & Low & 61 & 16.98 & 10.78 & & & \\
\hline
\end{tabular}

$(\mathrm{N}=111)$

Table No: IV, Shows the mean scores of Study Habits and Attitudes Inventory between High and Low group of college students are 18.62 and 16.98 respectively. The " $t$ " value difference between High and Low group of college students are 2.13, which is significant at 0.05 level. The table value is 1.98 at $109 \mathrm{df}$. Therefore, the null hypothesis is rejected in favor of the alternative 
hypothesis. This indicates that a significant difference exists between the high Study Habits group better than the low Study Habits group in terms of Achievement Motivation.

\section{CONCLUSIONS}

1. The positive and significant relationship has been found between Study Habits and Attitudes Inventory and Achievement Motivation of college students

2. The Male and Female are equal in Study Habits and Attitudes Inventory of college students.

3. The Male and Female are equal in Achievement Motivation of college students.

4. The high group of Study Habit students has achieved high results in Achievement then the low group of Study Habits students.

\section{REFERENCE}

Anderson, Robert, P. and Kuntz, \& James, E. The Survey of Study Habits and Attitude's In a College Counselling Center, Personn, Guide. Journal.

Garrett, H.E. (1958). Statistics in Psychology and Education, (5 $5^{\text {th }}$ Ed.). Longmans, Green and Co., New York.

Jamuar, K,K. (1973). Study Habit of College Student, Indian International Publications,P.B.79,Allahabad:India.

McClelland, D.C., Atkinson, J.W., Clark, R.A. \& Lowell, E.L. The Achievement Motive, New York, Appleton Century Crofts, Inc, 1953.

Wrenn, Gilbert, C. (1941). Manual of The Directions of The Study Habit Inventory, Revised Ed, Stanford University Press, California, 01-06. 